\title{
Late-onset focal dermal elastosis
}

INSERM

\section{Source}

INSERM. (1999). Orphanet: an online rare disease and orphan drug data base. Late-onset focal dermal elastosis. ORPHA:228227

Late-onset focal dermal elastosis is a rare, acquired, dermis elastic tissue disorder characterized by a pseudoxanthoma elasticum-like papular eruption consisting of multiple, slowly progressive, asymptomatic, 2-5 mm, white to yellowish, non-follicular papules (that tend to form cobblestone plaques) predominantly distributed over the neck, axillae and flexural areas, with no systemic involvement. Skin biopsy reveals a focal increase of normal-appearing elastic tissue in the reticular dermis with no calcium deposits. 